UDK 80

DOI: $10.24044 / \mathrm{sph} .2017 .1 .11$

\title{
IMMOBILITY AS ONE OF KEY IMAGES IN FICTION BY S. TOWNSEND
}

\author{
A. I. Dzyubenko \\ L. D. Tamrazova
}

Candidate of Philological Sciences assistant professor student

Southern Federal University

Rostov-on-Don, Russia

\begin{abstract}
The article touches upon the ways S. Townsend chose for portraying one the key images in the history of both English and Russian literature - the image of immobility. This image helps the author to suggest the readers different methods of fighting with depression by putting the protagonists into the same physical and psychological conditions - they are both in their beds and are suffering from depression. But the differences lie in the sources of this destructive emotion (either enforced by the outer impetuses or the fictional character him/herself), in the keeping/not keeping touch with the environs and, finally, in the desire/ non-desire to get back to normal, full of mobility life.
\end{abstract}

Keywords: epithet; physical and mental comfort; protagonist; deterioration of one's state.

Putting the words of the Russian outstanding classic into the contemporary framework we would say that every unhappy person is unhappy in his own way. No one doubts that every of us is a unique individual and the way we get over negative emotions depression, for instance - is peculiar for each of us. Still, there are some axiomatized ways people resort to for distancing themselves from the outside world that, as they think, is too cruel and unfair with them. The protagonists of Sue Townsend's novels "The woman Who Went to Bed for a Year" (Eva) and "Queen and I" (Prince Phillip) choose the same way to overcome the problems - they both remain in bed instead of sharing the grave life circumstances and problems with their families, instead of struggling for the better and more stable future both for themselves and their close people.

As for Eva, the day her children leave home, she climbs into bed and stays there. What made her unhappy? No one died, nor any huge loss happened, she isn't abandoned by children - they are going to visit her from time to time. Moreover, she is free from domestic chores and other duties: "On the second day Eva woke and threw the duvet back and sat on the side of the bed. Then she remembered that she didn't have to get up and make breakfast for anyone, yell at anyone else to get up, empty the dishwasher..." [2, p. 27]. So having a lot of free time she chooses to spend it in bed. The protagonist finds it the best way to think back of her life. In fact, "she didn't know it would be a year. 
She climbed into bed thinking she would leave it again after half an hour, but the comfort of the bed was exquisite, the white sheets were fresh and smelled of the new snow. She turned on her side towards the open window and watched the sycamore in the garden shed its blazing leaves" [2, p. 2]. The noun "comfort" accompanied by the epithet "exquisite" makes it clear that Eva is in search of both physical and mental convenience that will contribute to her finally acquiring emotional stability. The abundance of similes makes the feeling of insecurity stronger and more concrete. At the very thought of being out of the bed, she feels uncomfortable as if everything around is dangerous: "It felt wrong when she put her feet on the floor, as though the carpet were a lagoon with piranha fish waiting to nibble at her toes" $[2$, p. 76].

People usually need the comforting when they are getting over some tragedies of life or at least some difficult or dangerous situations. So it may seem that in the case of Eva her children's departure is that very kind of tragedy. But she isn't sure herself what exactly she is escaping from: "She felt that if she stayed on the sheet she would be safe - though from what, she didn't know" [2, p. 84]. Then comes her first attempt to get out of bed, but she consciously makes the decision to remain in it: no matter what was going on (whether her children came back, or the truth about her husband's affair was revealed, or her mother-in-law died) Eva stayed in bed: "She felt as though she had fallen into a vat of a warm quick- setting concrete, and that she was powerless to move. She felt an exquisite languor spread throughout her body, and thought, 'I would have to be mad to leave this bed" [2, p. 105].

But Eva shows the interest to the world around, especially to the people's problems. She makes new friends - Mark the window cleaner and Alexander, a handyman and gets known all over the world. Journalists and ordinary people are eager to talk to Eva, to tell about their problems and to ask for help. There is an obviously intense work of her psyche looking for the straws for getting her out of the depression moor, which is not the case with the protagonist of another novel by S. Townsend "The Queen and I" Prince Phillip. The scene is laid when a republican party wins the general election and the Royal Family is sent to live in a housing estate in the Midlands. Exchanging Buckingham Palace for a two-bedroomed semi in Hell Close (as the locals dub it), caviar for boiled eggs, servants for a social worker, the Queen and Prince Phillip are to learn what it means to be poor among the great unwashed.

Most stressfully Prince Phillip gets over the troubles which, when compared with Eva's ones, are really serious. All his traditional comfortable world is ruined at once, he is devastated and can't find inner power to get over them with his head high. Instead, he goes to bed and finds a physical and psychological refuge in there. At first he hides all his sufferings and keeps silent with the royal relatives lest to be taken to emotional and sensitive by 
them: "The atmosphere between the Queen and Prince Philip was awkward as they washed and undressed for bed. Furniture filled every room. They had to squeeze past each other with frequent apologies for touching. Finally, they lay in bed in the grey light of morning thinking about the horrors of the previous day and of the horrors to come" [1, p. 31]. It is the first time the image of a bed is introduced into the narration but it is the starting point of its development within the narrative structure. This image will get humongous sizes the longer Prince Phillip remains in bed. There is a direct correlation between the time spent in bed and the narration pieces devoted to its or Prince Phillip's health description.

And here we are to draw a border line between the similarities the image of immobility gets in two novels. The differences in its description start when the author portrays the everyday duties of the protagonists and their ways of having the communication with the outside world. If Eva makes new friends, takes care of hygiene and conventional things, Prince Phillip refuses to accomplish the everyday duties, to shave or to put off his pajamas: "Nothing. Lying in bed. Now, leave my breakfast tray and close those bloody curtains and go out, would you?" [1, p. 58]. These emotionally marked epithets and elliptical sentences convey his desperate decision not to leave the bed and stay there for as long as possible. He decides to isolate himself both from everyone and everything around, as he asks to close the curtains.
As the novel unfolds, we're witnessing the deterioration of his state: "He wouldn't talk, he wouldn't move, wouldn't eat now. It was absolutely infuriating. It was time to call the doctor again" [1, p. 174]. It's the last scene in the book with Prince Phillip: it doesn't mean that he dies, he stays in bed while his family's fighting a difficult battle of being moved into the outlandish for them social and financial conditions. If Phillip never again won back his mobility from depression, Eva definitely is on the way to getting victory. Her inner anxiety influences her appearance and soon she loses weight, her skin is flaky and it seems that she's losing too much hair. In the end, Eva suffers panic when she realizes that she's alone in the dark house: "In the early hours of the $19^{\text {th }}$ of September, Eva woke to darkness. She immediately broke into a cold sweat. She was afraid of the dark" [1, p. 432]. The feeling of privacy didn't comfort her any more. Alexander was the person who came to get her out of the room: "When the door was fully open, he saw her on the bed hunched against the boarded-up window". When he carried her into the sitting room and put her on the sofa on front of the fire, the one and only thought in her head was "it's kindness" [2, p. 437].

So both protagonists choose the same way of getting over the difficult period of time. Philip, unlike Eva, endures the real changings in his life that he can't brook it. He can't live the same life and finds the solution in staying alone in bed. In "The Queen and I" the image of immobility (the 
symbol of which is bed in narration) isn't as much described as in the "The Woman Who Went to Bed for a Year". But almost every scene is set in bed and during the whole story he is in it, with his head on the pillow and his eyes closed. Eva longs to stay in bed since the birth of her children. Going to bed for a year is her intended decision and she enjoys every second being in bed, and so the image of immobility, of a bed is enhanced through the use of similes and epithets.

It may seem that Phillip suffers more as his depression is accompanied by greater health deterioration and it takes little time till his inner state is in full harmony with his appearance. As for Eva, she also doesn't look the same, the depression ruins her beauty. It's also important to underscore that Phillip deliberately loses touch with the world outside. The reader doesn't witness the evolution of his image through the novel, but Eva, on the contrary, makes more friends and becomes more popular among acquaintances.

The image of immobility helps the author to suggest the readers different ways of fighting with depression by putting the protagonists into the same physical and psychological conditions - they are both in their beds and are suffering from depression. But the differences lie in the sources of this destructive emotion (either enforced by the outer impetuses or the fictional character him/herself), in the keeping/not keeping touch with the environs and, finally, in the desire/ nondesire to get back to normal, full of mobility life.

\section{Bibliography}

1. Townsend S. The Queen and I. - London : Penguin Books, 2012. - 267 p.

2. Townsend S. The Woman Who Went to Bed for a Year. - London : Penguin Books, 2011. - 437 p.

(C) Dzyubenko A. I., Tamrazova L. D., 2017. 